\title{
KEMAMPUAN PENYESUAIAN DIRI MAHASISWA TERHADAP PEMBELAJARAN DARING DI TENGAH PANDEMI COVID-19
}

\author{
Qori Fanani $^{1)}$, Janes Jainurakhma ${ }^{2)}$ \\ ${ }^{1}$ Keperawatan, Sekolah Tinggi Ilmu Kesehatan Kepanjen, \\ email: qori.fanani1084@gmail.com \\ ${ }^{2}$ Keperawatan, Sekolah Tinggi Ilmu Kesehatan Kepanjen, \\ email: janesjainurakhma.nuryadi@gmail.com
}

\begin{abstract}
Abstrak
Penelitian ini bertujuan untuk mengetahui kemampuan penyesuaian diri mahasiswa semester I terhadap pembelajaran daring di tengah pandemi covid-19. Jenis penelitian yang digunakan adalah kuantiatif dengan metode survey kepada 80 responden, instrumen yang digunakan adalah kuesioner penyesuaian diri Scheneider yang berbentuk skala likert dan terdiri dari 36 pernyataan. Hasil analisis data menggunakan chi-square menunjukkan p-value <0,001, hal ini menunjukkan terdapat hubungan antara penyesuaian diri dengan efektifitas pembelajaran daring. Sebagian besar responden memiliki tingkat penyesuaian tinggi terhadap pembelajaran daring, dan beberapa diantaranya sudah terbiasa dengan pembelajaran tersebut. Hasil penelitian ini mengindikasikan dengan adanya kemampuan penyesuaian diri yang bervariasi diantara mahasiswa, maka perlunya inovasi dan variasi terhadap pembelajaran daring kedepannya, supaya mahasiswa tidak cepat bosan, adaptable terhadap metode pembelajaran daring, sehingga materi yang diberikan dosen sebagai fasilitator dapat tersampaikan dengan lebih baik sesuai dengan capaian pembelajaran lulusan.
\end{abstract}

Keywords: kemampuan penyesuaian diri, mahasiswa, pembelajaran daring, pandemi covid-19

\section{PENDAHULUAN}

Pada saat ini, dunia sedang dilanda wabah penyakit yang bernama coronavirus yang dapat menyebabkan penyakit infeksi saluran pernafasan seperti flu, MERS dan SARS (Setiawan \& Ilmiyah 2020). Virus ini di sinyalir mulai mewabah pada bulan Desember 2019 di kota Wuhan Propinsi Hubei China (Hui, et al., 2020) yang kemudian menyebar ke seluruh penjuru dunia dengan sangat cepat hingga saat ini, sehingga WHO menetapkan ini menjadi pandemi global.

Dampak dari covid-19 ini sangat luas, tidak hanya kondisi fisik, namun dengan adanya berita tentang banyaknya korban yang berjatuhan dan penyebaran nya yang sangat cepat sampai menimbulkan kematian, mempengaruhi kondisi psikologis atau mental seseorang seperti kecemasan akut. Sebagai upaya untuk memutus penyebaran virus ini, maka pemerintah mengeluarkan kebijakan melalui Surat Edaran Nomer 3 Tahun 2020 tentang Pencegahan Covid-19 sebagai panduan dalam menghadapi penyakit tersebut di tingkat satuan pendidikan (Kemendikbud, 2020). Lebih lanjut, UNESCO pada 4 Maret 2020 menyarankan penggunaan pembelajaran jarak jauh dan membuka platform pendidikan yang dapat digunakan sekolah dan guru untuk menjangkau peserta didik dari jarak jauh dan membatasi gangguan pendidikan (UNESCO, 2020).

Menurut berita di kompas (26 Maret 2020) tercatat 276 perguruan tinggi negeri dan swasta di Indonesia yang menerapkan kuliah daring atau online. Perkuliahan daring dapat dipahami sebagai pendidikan formal yang diselenggarakan oleh perguruan tinggi yang peserta didiknya dan instruktur (dosen) berada di lokasi terpisah sehingga memerlukan system telekomunikasi interaktif untuk 
menghubungkan keduanya dan berbagai sumberdaya yang diperlukan didalamnya.

Bagi mahasiswa, pembelajaran jarak jauh atau online memang sudah familiar. Hanya saja, tehnis pembelajaran dan metode pembelajaran belum mampu memuaskan dosen dan mahasiswa itu sendiri. Meskipun banyak sekali platform pembelajaran yang tersedia antara lain seperti whatsapp, google classroom, zoom, sevima edlink, schoology dan masih banyak lagi. Tentunya platform menjadi kurang efektif dalam penggunaannya dikarenakan oleh beberapa faktor antara lain kemampuan dosen maupun mahasiswa dalam mengoperasikannya tidaklah sama, selain itu kondisi geografis suatu daerah berbeda sehingga berpengaruh kepada kestabilan jaringan internet (Pangondian, Santosa dan Nugroho, 2019)

Kompleksitas permasalah selama pembelajaran daring dialami oleh pihak dosen, mahasiswa, dan orang tua, dimana problematika terbesar pada penguasaan informatika dan teknologi (Asmuni, 2020; Roni Hamdani \& Priatna, 2020) dan keterbatasan kuota internet ataupun sarana dan prasarana yang dibutuhkan selama daring berlangsung (Nursobah, Dedih, Hafid, \& Nurhamzah, 2020). Problematika tersebut menjadi tantangan bagi mahasiswa untuk mampu menyesuaikan diri dan lebih mandiri dalam proses pembelajarannya. Hal ini dikarenakan yang terjadi dalam proses pembelajaran jarak jauh lebih mengarah pada penugasan dengan pembatasan waktu untuk menggantikan kehadiran mahasiswa.

Padahal, jika dilihat lebih dalam, tingkatan kompleksitas pembejaran online jauh lebih rumit daripada pembelajaran offline karena umpan balik memang menjadi point penting karena mahasiswa bahkan bisa mencari materi dari internet dengan beberapa kali sentuhan. Pembelajaran daring memiliki keunikan tersendiri yang harus diperhatikan diantaranya keterampilan mahasiswa untuk belajar mandiri, kemampuan berkolaborasi dengan dosen dan juga mahasiswa yang lain, serta kreatifitas dosen selaku fasilitator pembelajaran daring dalam menyampaikan materi dan membimbing mahasiswa mencapai capaian pembelajran lulusan yang telah ditetapkan di dalam kurikulum tiap-tiap program studi (Sudarsana \& dkk, 2020).

Perubahan inilah yang mempengaruhi kondisi psikologis seseorang karena kesiapan setiap individu dalam menyesuaikan diri dengan kondisi-kondisi tertentu juga berbedabeda. Sigmund Freud menyatakan bahwa secara alami setiap manusia melakukan mekanisme pertahanan ego untuk berhadapan dengan ancaman dari luar yang menimbulkan pertentangan terhadap kepercayaan dalam diri. Tingkat ketahanan mental seseorang juga akan mempengaruhi proses kognitifnya dalam menghadapi perubahan yang akan menimbulkan persepsi dan pemahaman yang berbeda. Hal ini juga akan membuat imunitas tubuh menjadi menurun dan rentan kepada kondisi kesehatan seseorang. Untuk itu setiap individu harus mampu melakukan penyesuaian diri.

Menurut Schneider (Fajriana, Yulizar, Bahri, \& Bakar, 2020) Penyesuaian diri adalah suatu proses dimana individu berusaha untuk mengatasi atau menguasai kebutuhan dalam diri, ketegangan, frustasi, dan konflik, dengan tujuan untuk mendapatkan keharmonisan dan keselarasan antara tuntutan lingkungan dimana ia tinggal dengan tuntutan di dalam diri sendiri. Selama masa pandemi ini, banyak peserta didik yang akan mengalami kendala dalam penyesuaian diri dengan berbagai hal baru yang harus diikuti dalam kehidupan new normal yang mulai diterapkan.

Perkuliahan itu sendiri "terrible phase" merupakan stressor tersendiri bagi mahasiswa baru "culture shock"seperti ide baru, karakter teman dengan keyakinan bervariasi (Cintia Astrina, 2019), banyak tekanan menghadapi periode transisi dalam menghadapi pembelajaran orang dewasa, sehingga penyesuaian diri merupakan kunci sukses dari 
mahasiswa baru (Mitasari \& Istikomayanti, 2019). Untuk menyesuaikan diri, individu melakukannya dalam berbagai bentuk seperti menghadapi secara langsung, melakukan eksplorasi, trial and error, subsitusi, menggali kemampuan diri, belajar, pengendalian diri, perencanaan yang cermat (Hartinah, 2008: 186)

Schneiders (dalam Hartinah 2008: 186) mengungkapkan bahwa kegagalan dalam melakukan penyesuaian diri secara positif dapat mengakibatkan individu bertingkah laku serba salah, tidak tararah, emosional, sikap yang tidak realistic dan agresif. Hal ini tentunya tidak lepas dari faktor-faktor yang mempengaruhi penyesuaian diri seseorang yaitu kondisi fisik, (hereditas, system utama tubuh dan kesehatan fisik), kepribadian (kemauan dan kemampuan untuk berubah, pengaturan diri, realisasi diri dan intelegensi), proses belajar (bejaran, pengalaman, latihan, determinasi diri), lingkungan (lingkungan keluarga, sekolah, masyarakat) dan agama serta budaya.

Berdasarkan permasalahan yang telah dijabarkan diatas, maka tujuan penelitian ini adalah mengetahui sejauh mana penyesuaian diri mahasiswa terhadap efektifitas pembelajaran daring ditengah pandemi covid-19.

\section{METODE PENELITIAN}

Penelitian ini menggunakan metode elektronik-survey (menggunakan google form) dengan menggunakan kuesioner penyesuaian diri Schneider yang berbentuk skala likert sebanyak 36 pernyataan. Populasi dalam penelitian ini adalah semua mahasiswa baru Sekolah Tinggi Ilmu Kesehatan Kepanjen tahun akademik 2020/2021 yang berjumlah 80 orang, total sampling dilakukan dalam penelitian ini dengan lama penelitian mulai SeptemberNovember 2020. Seluruh responden yang terlibat dalam penelitian ini telah melakukan pembelajaran daring selama September hingga November 2020, pembelajaran daring kepada mahasiswa diberikan melalui whatsapp group, zoom, google classroom, schoology, youtube sesuai dengan jadwal yang telah diberikan oleh masing-masing program studi.

Analisa data menggunakan chi square untuk melihat sejauh mana penyesuaian diri berpengaruh terhadap pembelajaran daring. Informed consent telah dilakukan diawal penelitian dan anonimity untuk menjaga kerahasiaan dari identitas responden.

\section{HASIL DAN PEMBAHASAN}

\section{Hasil}

Responden dalam penelitian ini terdiri dari tiga program studi (Prodi) yaitu Prodi Keperawatan Program Sarjana, Program Diploma III Keperawatan dan Administrasi Rumah Sakit (ARS). Dengan sebaran yang ditunjukkan pada tabel 1, dimana sebagian besar berasal dari mahasiswa Prodi Keperawatan Program Sarjana (62,5\%).

Tabel 1. Sebaran responden penelitian dilihat dari Program Studi responden

Responden Frekuensi Prosentase

\begin{tabular}{ccc} 
& & $(\%)$ \\
\hline Prodi ARS & 7 & $8.75 \%$ \\
\hline $\begin{array}{c}\text { Prodi DIII } \\
\text { Keperawatan }\end{array}$ & 23 & $28.75 \%$ \\
\hline $\begin{array}{c}\text { Prodi S1 } \\
\text { Keperawatan }\end{array}$ & 50 & $62.5 \%$ \\
\hline$\quad$ Total & 80 & $100 \%$ \\
\hline (Sumber: data primer penelitian, November 2020)
\end{tabular}

Tabel 2. Karakteristik Umum Responden

\begin{tabular}{|c|c|c|c|}
\hline \multicolumn{2}{|c|}{ Karakteristik } & $\mathbf{n}$ & $\%$ \\
\hline \multirow{2}{*}{$\begin{array}{l}\text { Jenis } \\
\text { kelamin }\end{array}$} & Laki-laki & 22 & 27.5 \\
\hline & Perempuan & 58 & 72.5 \\
\hline \multirow{2}{*}{$\begin{array}{l}\text { Pembelajaran } \\
\text { daring }\end{array}$} & Pernah & 19 & 23.8 \\
\hline & Tidak pernah & 61 & 76.2 \\
\hline \multirow{6}{*}{ Usia } & 17 tahun & 5 & 6.25 \\
\hline & 18 tahun & 46 & 57.5 \\
\hline & 19 tahun & 19 & 23.75 \\
\hline & 20 tahun & 4 & 5 \\
\hline & 21 tahun & 5 & 6.25 \\
\hline & 22 tahun & 1 & 1.25 \\
\hline
\end{tabular}




\begin{tabular}{|c|c|c|c|}
\hline \multirow[t]{6}{*}{$\begin{array}{l}\text { Pendidikan } \\
\text { terakhir }\end{array}$} & $\begin{array}{l}\text { SMU } \\
\text { Jurusan IPA }\end{array}$ & 32 & 40 \\
\hline & $\begin{array}{l}\text { SMU } \\
\text { Jurusan IPS }\end{array}$ & 9 & 11.25 \\
\hline & $\begin{array}{l}\text { SMK } \\
\text { Keperawatan }\end{array}$ & 28 & 35 \\
\hline & $\begin{array}{l}\text { SMK non } \\
\text { keperawatan }\end{array}$ & 8 & 10 \\
\hline & $\begin{array}{l}\text { MA Jurusan } \\
\text { IPA }\end{array}$ & 1 & 1.25 \\
\hline & $\begin{array}{l}\text { MA jurusan } \\
\text { IPS }\end{array}$ & 2 & 2.5 \\
\hline
\end{tabular}

Karakteristik umum responden pada tabel 2, didominasi dengan perempuan $(72,5 \%)$, dengan usia remaja dengan rentang 18-19 tahun (81,25\%), dan sebelumnya mereka belum pernah melakukan pembelajaran secara daring (76,2 \%), dengan pendidikan terakhir responden berlatar belakang pendidikan exact IPA dan SMK Keperawatan $(76,25 \%)$.

Tabel 3. Zona wilayah responden

$$
\text { Wilayah n Prosentase }
$$

\begin{tabular}{llc}
\hline $\begin{array}{l}\text { Kab. Malang } \\
-\begin{array}{l}\text { Zona 1 Kepanjen, } \\
\text { Sumberpucung, }\end{array}\end{array}$ & 41 & 51.25 \\
$\begin{array}{l}\text { Gondanglegi, Turen } \\
\text { Pakisaji dll) }\end{array}$ & 2 & \\
$-\begin{array}{l}\text { Zona } \\
\text { (Ampelgading, } \\
\text { Tumpang, } \\
\text { Kasembon, } \\
\text { Poncokusumo dll) }\end{array}$ & 28 & 35 \\
\hline Kota Malang & 2 & 2.5 \\
\hline Batu & 1 & 1.25 \\
\hline Kab. Blitar & 2 & 2.5 \\
\hline Kab. Lumajang & 1 & 1.25 \\
\hline Bali & 2 & 2.5 \\
\hline Jambi \& Riau & 2 & 2.5 \\
\hline Kab. Ponorogo & 1 & 1.25 \\
\hline TOTAL & 80 & 100 \\
\hline
\end{tabular}

(Sumber: data primer penelitian, November 2020)

Tempat tinggal responden didominasi tersebar di wilayah Kabupaten Malang. Zona 1 merupakan kecamatan terdekat dengan wilayah kampus (STIKes Kepanjen) (51.25\%) sedangkan zona 2 adalah zona yang terletak lebih jauh dari kampus dan merupakan daerah pegunungan $(35 \%)$ dan sisanya adalah responden yang berada di luar kabupaten Malang (13.75\%).

Hasil dari survey kemampuan penyesuaian diri mahasiswa baru dikategorikan menjadi 5, diantaranya: sangat tinggi, tinggi, sedang, rendah dan sangat rendah, seperti pada tabel 4 .

Tabel 4. Tingkat penyesuaian diri mahasiswa terhadap pembelajaran daring

\begin{tabular}{lcc}
\hline \multicolumn{1}{c}{ Kategori } & Frekuensi & Prosentase (\%) \\
\hline Sangat tinggi & 15 & 18.75 \\
\hline Tinggi & 30 & 37.5 \\
\hline Sedang & 22 & 27.5 \\
\hline Rendah & 8 & 10 \\
\hline Sangat rendah & 5 & 6.25 \\
\hline \multicolumn{1}{c}{ TOTAL } & $\mathbf{8 0}$ & $\mathbf{1 0 0}$ \\
\hline
\end{tabular}

(Sumber: data primer penelitian, November 2020)

Kemampuan penyesuaian diri yang bervariasi dari mahasiswa baru terhadap pembelajaran daring yang diterapkan di Sekolah Tinggi Ilmu Kesehatan tampak pada tabel 3, data menunjukkan hasil yang positif dimana kemampuan penyesuaian diri yang baik sebesar 56,25\% (tingkat penyesuaian tinggi dan sangat tinggi).

Tabel 5. Hasil analisis statistik (chi-square)

\begin{tabular}{cc|c|c|c|c|c}
\hline \multirow{2}{*}{ Kategori } & \multicolumn{3}{|c|}{ Pembelajaran daring } & \multirow{2}{*}{ p-value } \\
\cline { 3 - 6 } & \multicolumn{2}{|c|}{ Efektif } & \multicolumn{2}{c}{$\begin{array}{c}\text { Tidak } \\
\text { efektif }\end{array}$} & \\
\cline { 3 - 6 } & $\mathrm{n}$ & $\%$ & $\mathrm{n}$ & $\%$ & \\
\hline \multirow{2}{*}{$\begin{array}{c}\text { Peny } \\
\text { esuai } \\
\text { an } \\
\text { diri }\end{array}$} & $\begin{array}{l}\text { Sangat } \\
\text { Tinggi }\end{array}$ & 8 & 53.3 & 7 & 46.7 & $<0.001$ \\
\cline { 2 - 6 } & Tinggi & 27 & 90 & 3 & 10 & \\
\cline { 2 - 6 } & Sedang & 17 & 77.3 & 5 & 22.7 & \\
\cline { 2 - 6 } & Rendah & 2 & 25 & 6 & 75 & \\
\cline { 2 - 5 } & $\begin{array}{c}\text { Sangat } \\
\text { rendah }\end{array}$ & 1 & 20 & 4 & 80 & \\
\hline
\end{tabular}


(Sumber: hasil analisis uji chi-square)

Dari hasil analisis uji statistik dengan chi-square menunjukkan bahwa $p$ value sebesar <0,001, maka dapat disimpulkan bahwa terdapat hubungan antara penyesuaian diri mahasiswa dengan efektifitas pembelajaran daring yang telah diberikan oleh fasilitator. Data survey menunjukkan tingkat penyesuaian diri mahasiswa sangat tinggi yang berdampak terhadap keefektifan dari daring sangat tinggi, sebesar $68,8 \%$, hal ini berdampak positif terhadap proses belajar mengajar yang dilakukan oleh dosen fasilitator selama pembelajaran daring dimasa pandemi covid-19.

\section{Pembahasan}

Pembelajaran di tengah pandemi covid-19, mengharuskan mahasiswa baru bertransformasi $100 \%$ pembelajaran dilakukan secara daring dengan berbagai pendekatan berbagai media elektronik melalui: whatsapp group, zoom, google classroom, schoology, youtube. Berbagai macam media elektronik digunakan sebagai fasilitas pembelajaran daring, dengan harapan capaian pembelajaran lulusan dapat terpenuhi dengan seoptimal mungkin. Hal ini menunjukkan bahwa penyesuaian metode pembelajaran dan media yang tepat dari seorang dosen merupakan salah satu penentu keberhasilan atau keefektifan pembelajaran bagi mahasiswa di tengah pandemi covid-19, dan membantu mahasiswa adaptable terhadap perubahan yang terjadi di masa pandemi (Fajriana et al., 2020; Mansyur, 2020).

Hasil analisis uji statistik dengan chi-square menunjukkan bahwa p-value sebesar $<0,001$ menunjukkan adanya pengaruh yang significant akan kemampuan penyesuaian diri mahasiswa tingkat I terhadap keefektifan pembelajaran daring yang diberikan kepada mahasiswa selama pandemi covid-19. Hasil penelitian ini bertolak belakang dengan penelitian Saniskoro and Akmal (2020) dan Limbong (2020) yang menyatakan ketidakefektifan pembelajaran daring pada mahasiswa tingkat I, lebih lanjut menyatakan bahwa $95.9 \%$ mahasiswa mengalami stress akademik yang dipengaruhi oleh faktor lain seperti kemampuan mahasiswa dalam melakukan manajemen waktu, beban keuangan, interaksi dengan dosen, kegiatan sosial dan dukungan sosial. Hasil penelitian yang dilakukan di STIKes Kepanjen menunjukkan mahasiswa dalam melakukan kegiatan belajar mengajar selama pandemi covid-19, mampu mengubah diri untuk mengikuti tuntutan perubahan dan keadaan lingkungan selama pandemi.

Mahasiswa baru sebagai responden 91\% adalah mahasiswa berlatarbelakang pendidikan keperawatan dengan memiliki kemampuan penyesuaian diri yang tinggi dan keefektifan dalam pembelajaran daring, menurut Aswandi (2017) mahasiswa keperawatan memiliki kecerdasan spiritual tinggi, sehingga mempengaruhi kemampuan dalam menanggulangi stress lebih baik dan mampu menahan diri dari perilaku yang destruktif meskipun dalam kondisi sesulit apapun (Ilmi \& Indrawati, 2019), emosi menjadi stabil dan mampu mengkompromikan diri sendiri dengan fakta yang ada di sekelilingnya. Hal ini akan berdampak positif pada kemampuan penyesuaian diri yang baik dan kemampuan memanajemen diri dalam pembelajaran daring, sehingga pembelajaran daring yang diberikan menjadi kondusif dan efektif bagi mahasiswa.

Hal ini sependapat dengan yang dilakukan pernyataan Schneiders bahwa penyesuaian diri merupakan suatu proses dinamis yang bertujuan untuk mengubah perilaku individu agar terjadi hubungan yang lebih sesuai antara diri individu dengan lingkungannya. Schneiders juga mendefinisikan penyesuaian diri dapat ditinjau dari 3 sudut pandang, yaitu penyesuaian diri sebagai bentuk adaptasi (adaptation), 
penyesuaian diri sebagai bentuk konformitas (conformity), dan penyesuaian diri sebagai usaha penguasaan (mastery) (Ali dan Asrori, 2006; Fajriani et al., 2020). Beberapa hal yang mampu mempengaruhi dinamika pembelajaran daring diantaranya kondisi pembelajaran, metode pembelajaran dan hasil pembelajaran (Mansyur, 2020; Saniskoro \& Akmal, 2020).

Kemampuan penyesuaian diri mahasiswa memiliki keterkaitan dengan jenis kelamin, dimana $72,5 \%$ responden adalah perempuan dan memiliki kemampuan penyesuaian diri yang baik dan memilki keefektifan yang tinggi terhadap pembelajran daring. Hal ini sesuai dengan penelitian yang dilakukan oleh Limbong (2020) yang menyatakan bahwa prestasi mahasiswa perempuan relatif lebih baik dibandingkan dengan mahasiswa laki-laki, begitu juga dengan seseorang yang berlatarbelakang pendidikan IPA dan keperawatan memiliki kecenderungan prestasi lebih baik di saat pandemi. Hal ini juga ditunjukkan dalam penelitian ini bahwa 76,25 \% mahasiswa (responden) berlatarbelakang pendidikan exact IPA dan SMK Keperawatan, meskipun 76,2\% mahasiswa belum pernah melakukan pembelajaran daring. Hal ini menunjukkan bahwa latar belakang pendidikan terakhir dan jenis kelamin memiliki kecenderungan berpengaruh terhadap kemampuan siswa dalam penyesuaian diri dan akhirnya berdampak pada keefektifan belajar mahasiswa di saat pandemi covid-19.

$$
\text { Sebagian besar }
$$

mahasiswa berusia remaja di rentang 18-19 tahun, menurut Fajriana et al. (2020) dan Mitasari and Istikomayanti (2017) penyesuaian diri mahasiswa juga dipengaruhi oleh lingkungan kuliah dan teman sebaya, semakin sering mereka berkomunikasi dan berinteraksi satu dengan yang lainnya, maka akan semakin tinggi tingkat kemampuan penyesuaian diri mahasiswa. Jika dikaitkan dengan masa pendemi ini, mahasiswa membutuhkan dukungan dari teman sebayanya untuk saling menguatkan dan memotivasi, sebab dengan lingkungan baru yang kondusif akan mempermudah mahasiswa dalam menyesuaikan diri dengan kebiasaan baru di tatanan pendidikan tinggi yang berbeda dengan budaya pembelajaran saat mereka di bangku sekolah. Motivasi mahasiswa itu akan memunculkan rasa puas dalam diri mahasiswa, dan akan nampak pada perubahan pada aspek kognitif, afektif dan psikomotor mahasiswa, dan tidak lupa kemampuan mahasiswa dalam menghadapi perubahan (Maulina \& Sari, 2018; Nalle, Saba, \& Masi, 2020).

Kemampuan dosen dalam mengembangkan metode pembelajaran daring yang kreatif, dengan diikuti ketersediaan sarana dan prasarana "technological paedagogical content knowledge" pembelajaran daring dari institusi akan meningkatkan minat belajar mahasiswa, kemampuan penyesuaian diri mahasiswa baru, keefektifan belajar-mengajar (perkuliahan) yang pada akhirnya berdampak pada kualitas capaian pembelajaran lulusan di tengah pandemi Covid-19.

\section{SIMPULAN}

Berdasarkan hasil penelitian dan pembahasan, maka dapat disimpulkan bahwa pembelajaran daring efektif bagi mahasiswa yang memiliki penyesuain diri pada kategori sedang, tinggi dan sangat tinggi. Bervariasinya tingkat penyesuaian diri dari mahasiswa semester I, perlu menjadikan masukan bagi dosen fasilitator mata kuliah. Dosen fasilitator perlu mengevaluasi keefektifan metode pembelajaran yang telah digunakan dan mengembangkan metode pembelajaran lainnya yeng berbasis daring. Hal ini perlu dilakukan oleh dosen dan seluruh tim akademisi perguruan tinggi dengan harapan mampu meningkatkan kualitas belajar mahasiswa dan kemampuan penyesuaian diri mahasiswa dalam pembelajaran jarak jauh di tengah pandemi covid-19. 


\section{UCAPAN TERIMAKASIH}

Penulis menyampaikan ucapan terima kasih kepada Sekolah Tinggi Ilmu Kesehatan (STIKes) Kepanjen, yang telah memberikan ijin dan memfasilitasi dilakukannya penelitian ini, dan seluruh responden yang telah berpartisipasi aktif.

\section{DAFTAR PUSTAKA}

Asmuni, A. (2020). Problematika Pembelajaran Daring di Masa Pandemi Covid-19 dan Solusi Pemecahannya. Jurnal Paedagogy, 7(4), 281. https://doi.org/10.33394/jp.v7i4.2941

Ali, M \& Asrori, M. (2006). Psikologi Remaja Perkembangan Peserta Didik. Jakarta: PT. Bumi Aksara.

Aswandi, F. (2017). Hubungan kecerdasan spiritual dengan tingkat stres pada mahasiswa keperawatan Universitas Tanjungpura Pontianak. (Naskah publikasi tidak diterbitkan). Program Studi Keperawatan Universitas Tanjungpura Pontianak, Pontianak.

Cintia Astrina, R. (2019). Hubungan kecerdasan emosi dengan penyesuaian diri pada mahasiswa tahun pertama jurusan psikologi. Jurnal Psikologi, 111.

Fajriana, Yulizar, Bahri, S., \& Bakar, A. (2020). PENYESUAIAN DIRI SISWA TERHADAP PEMBELAJARAN DARING DI SMA LABORATORIUM UNSYIAH PADA MASA PANDEMI COVID19. Prociding Seminar Nasioanal 2020 "Penguatan Pendidikan Karakter Pada Era Merdeka Belajar," 271-278.

Fajriani, Yulizar, Bahri, S., \& Bakar, A. (2020). Penyesuaian Diri Siswa Terhadap Pembelajaran Daring Di
Sma Laboratorium Unsyiah Pada Masa Pandemi Covid-19. Prosiding Seminar Nasional LP3M, 2, 271-278.

Ilmi, D., \& Indrawati, E. S. (2019). Hubungan antara Kecerdasan Spiritual dengan Penyesuaian Diri pada Mahasiswa Tahun Pertama Departemen Ilmu Kelautan dan Oseanografi Fakultas Perikanan dan Ilmu Kelautan Universitas Diponegoro Semarang. Empati, 9(Nomor 3), 90-102.

Limbong, A. (2020). Pengaruh Model Pembelajaran Daring Akibat Pandemi Covid- 19 Terhadap Prestasi Belajar Mahasiswa UNAI pada Semester The Effect of Online Learning Model due to Covid-19 Pandemic, on the Academic Achievement of UNAI Students in Even Semester, 161-168.

Mansyur, A. R. (2020). Dampak COVID-19 Terhadap Dinamika Pembelajaran Di Indonesia. Education and Learning Journal, $\quad 1(2), \quad 113$. https://doi.org/10.33096/eljour.v1i2.55

Maulina, B., \& Sari, D. R. (2018). Derajat Stres Mahasiswa Baru Fakultas Kedokteran Ditinjau Dari Tingkat Penyesuaian Diri Terhadap Tuntutan Akademik. Jurnal Psikologi Pendidikan Dan Konseling: Jurnal Kajian Psikologi Pendidikan Dan Bimbingan Konseling, 4(1), 1. https://doi.org/10.26858/jpkk.v4i1.4753

Mitasari, Z., \& Istikomayanti, Y. (2017). Studi pola penyesuaian diri mahasiswa luar Jawa di Universitas Tribhuwana Tunggadewi Malang. Seminar Nasional Dan Gelar Produk, (0341), 796-803.

Mitasari, Z., \& Istikomayanti, Y. (2019). Hubungan Antara Culture Shock Dengan Hasil Belajar Mahasiswa Tahun Pertama. Jurnal Psikologi Pendidikan Dan Konseling: Jurnal Kajian Psikologi Pendidikan Dan Bimbingan Konseling, 4(2), 105. https://doi.org/10.26858/jpkk.v4i2.4316 
Nalle, A. P., Saba, K. R., \& Masi, L. M. (2020). the Description of Guidance and Counseling Students' Learning Motivation in Taking Online- Based Learning During the Pandemic. JPEHSS (Journal of Physical Education Health And Sport Sciences), 1(September), 94-105.

Nursobah, A., Dedih, U., Hafid, \& Nurhamzah. (2020). Dampak Pembelajaran Daring terhadap Penguatan Literasi Informasi dalam Budaya Akademik Mahasiswa. UIN Sunan Gunung Djati, 1-8.

Pangondian, R. A., Santosa, P. I., \& Nugroho, E. (2019). Faktor - Faktor Yang Mempengaruhi Kesuksesan Pembelajaran Daring, 56-60.

Roni Hamdani, A., \& Priatna, A. (2020). Efektifitas Implementasi Pembelajaran
Daring (Full Online) Dimasa Pandemi Covid- 19 Pada Jenjang Sekolah Dasar Di Kabupaten Subang. Didaktik: Jurnal Ilmiah PGSD STKIP Subang, 6(1), 1-9. https://doi.org/10.36989/didaktik.v6i1.120

Saniskoro, B. S. R., \& Akmal, S. Z. (2020). Peranan penyesuaian diri di perguruan tinggi terhadap stres akademik pada mahasiswa perantau di Jakarta. Jurnal Psikologi Ulayat, 4(1), 96-106. https://doi.org/10.24854/jpu67

Setiawan, A. R., \& Ilmiyah, S. Lembar Kegiatan Siswa untuk Pembelajaran Jarak Jauh Berdasarkan Literasi Saintifik pada Topik Penyakit Coronavirus 2019 (COVID-19) (2020).

Sudarsana, I. K., \& dkk. (2020). COVID-19: Perspektif Pendidikan. Denpasar: Yayasan Kita Menulis. 